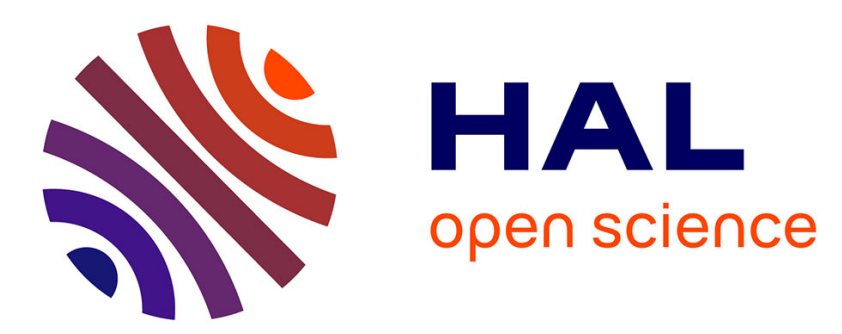

\title{
Acute sore throat revisited: clinical and experimental evidence for the efficacy of over-the-counter AMC/DCBA throat lozenges.
}

John Sydney Oxford, Martin Leuwer

\section{- To cite this version:}

John Sydney Oxford, Martin Leuwer. Acute sore throat revisited: clinical and experimental evidence for the efficacy of over-the-counter AMC/DCBA throat lozenges.. International Journal of Clinical Practice, 2011, 65 (5), pp.524. 10.1111/j.1742-1241.2011.02644.x . hal-00631701

\section{HAL Id: hal-00631701 \\ https://hal.science/hal-00631701}

Submitted on 13 Oct 2011

HAL is a multi-disciplinary open access archive for the deposit and dissemination of scientific research documents, whether they are published or not. The documents may come from teaching and research institutions in France or abroad, or from public or private research centers.
L'archive ouverte pluridisciplinaire HAL, est destinée au dépôt et à la diffusion de documents scientifiques de niveau recherche, publiés ou non, émanant des établissements d'enseignement et de recherche français ou étrangers, des laboratoires publics ou privés. 


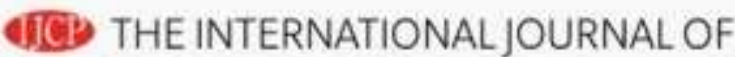 CLINICAL PRACTICE}

\section{Acute sore throat revisited: clinical and experimental evidence for the efficacy of over-the-counter AMC/DCBA throat lozenges.}

\begin{tabular}{|r|l|}
\hline Journal: & International Journal of Clinical Practice \\
\hline Manuscript ID: & IJCP-07-10-0349.R1 \\
\hline Wiley - Manuscript type: & Perspective \\
\hline Author: & $15-$ Oct-2010 \\
\hline Complete List of Authors: & $\begin{array}{l}\text { Oxford, John; Barts and the Royal London, Blizard Institute of Cell } \\
\text { and Molecular Science } \\
\text { Leuwer, Martin; Critital Care Research Unit School of Clinical } \\
\text { Sciences, The University of Liverpool }\end{array}$ \\
\hline \hline Specialty area: & \\
\hline
\end{tabular}


Acute sore throat revisited: clinical and experimental evidence for the efficacy of over-the-counter AMC/DCBA throat lozenges.

John S Oxford ${ }^{1 \star \S}$, Martin Leuwer ${ }^{2 \star}$

${ }^{1}$ Professor of Virology, Blizard Institute of Cell and Molecular Science, Bart's and The Royal London, Queen Mary's School of Medicine and Dentistry, London, UK

${ }^{2}$ Professor and Chair of Anaesthesia Head of Critical Care Research Unit School of Clinical Sciences, The University of Liverpool, Liverpool, UK

*Both authors contributed equally to the article

\section{${ }^{8}$ Corresponding author}

J.S. Oxford

Professor of Virology

Blizard Institute of Cell and Molecular Science

Bart's and The Royal London

2 Royal College Street

London, NW1 ONH

UK

Tel: 02071180727

Fax: 02030700086

Email: j.oxford@retroscreen.com

Total word count (main body of manuscript): $\sim 2900$ 


\section{Abstract (177 words)}

Acute sore throat is a minor, self-limiting ailment, but patients commonly seek advice and treatment for immediate symptomatic relief. However, most sore throats due to upper respiratory tract infections are viral in nature, and antibiotics often prescribed are not suitable for the treatment of sore throat, as reflected in many European guidelines.

Many topical treatments are available over the counter, including throat sprays, gargles and lozenges. We discuss some of the 'ideal' features of over-the-counter options in the treatment of simple sore throat cases. The main features include the direct targeting of the viral and inflammatory causes, the provision of local pain relief, rapid onset of action and prolonged duration of action, effectiveness over a range of different types of sore throat, an ability to address the emotional aspects associated with having a sore throat and a good safety profile. Some recent clinical and experimental evidence on the efficacy and postulated mechanism of action for amylmetacresol and 2,4-dichlorobenzyl alcohol-containing lozenges, that have been marketed for many years are also discussed as an illustration of such targeted approach. 


\section{Introduction}

Recent events of the human influenza (H1N1 virus) pandemic have exposed a central role for sore throat in the basic clinical presentation of the disease (1). 'Acute sore throat' is a term often used to describe pharyngitis, tonsillitis and laryngitis that occur for a short period of time. On average, regardless of a pandemic influenza year, an adult may experience 2-3 sore throats over a period of 12 months, whereas children are more susceptible and are likely to experience more sore throat episodes (2), because of their immune naivety. With the imminent re-emergence of flu season in the UK, it would appear an opportune moment to revisit the role of self-prescribed sore throat remedies that, alongside NHS Direct in the United Kingdom (UK), can alleviate pressures on general practitioners. The symptoms of sore throat vary between individuals and include a local mild discomfort with a scratchy-like sensation, swelling, pain with a 'raw' sensation and difficulty in swallowing (3). Most cases of acute sore throat due to upper respiratory tract infections (URTIs), caused by a range of viruses, are generally not serious and are self-limiting, usually improving within 1 week $(3,4,5)$.

A recent report by the Royal College of General Practitioners in the UK documented an agestandardised person prevalence rate of 182 per 10,000 for acute pharyngitis in the year 2007. Furthermore, they reported a patient consultation rate of 182 per 10,000 persons for all ages (6). Current recommendations are to avoid unnecessary prescribing of antibiotics (7-10). Therefore, an understanding of the leading causes of sore throat and the availability of effective over-the-counter (OTC) treatment options as a recommendation for patients who present at surgeries, are becoming increasingly important.

\section{Causes of acute sore throat}

Viruses have been associated with $50-95 \%$ of sore throats in adults $(11,12)$, and linked to $70 \%$ of sore throats in children between the ages of 5-16 years, and $95 \%$ in under 5 s (12). The viral causes of sore throat are numerous and include respiratory viruses such as respiratory syncytial viruses, rhinoviruses and influenza $A(13,14)$. A global analysis of the prevalence of patients with human influenza ( $\mathrm{H} 1 \mathrm{~N} 1$ virus) reporting sore throat as a symptom ranged from $26 \%$ (in the UK) to $39 \%$ (in Japan) (1).

It is possible that bacterial causes may be underestimated and may contribute up to $20 \%$ of all sore throat aetiologies (15). Therefore, it is important that cases of sore throat due to streptococcal infections are correctly identified with appropriate antibiotics prescribed. Other 
causes of sore throat include environmental influences, such as temperature changes, low humidity, smoking, air pollution and a reaction to allergens, among other factors (7).

\section{Pro-inflammatory cytokines and acute sore throat}

Irrespective of the cause, a sore throat manifests as irritating symptoms such as pain and irritation, and is most likely to be caused by inflammatory mediators, e.g. bradykinin and prostaglandins, which are released following local responses to cell damage and exert their effect on sensory nerves in the airways (16). In addition, pro-inflammatory cytokines have been associated with sickness behaviour (17), which, in turn, is associated with increased pain sensitivity in cases of microbial infection (17). Because most sore throats are infective in nature and sore throat-induced pro-inflammatory cytokines are linked with sickness behaviour, there may be potential implications to the quality of life of sufferers where there is associated viral or bacterial infection. A study in young adults with suspected viral sore throat has demonstrated a high correlation between sore throat and 'sickness' (18). Furthermore, it has been found that sore throats have a significant impact on normal daily activities/functions of a patient, including swallowing, talking, eating a meal, sleeping and concentration (19).

\section{Associated cost burden}

Despite the high predominance of viral sore throats over any other causes in adults $(11,12)$, antibiotics are commonly prescribed by physicians for the treatment of acute sore throats $(20,21)$. Throughout the 1980 s, there was a progressive increase in the overall consumption of antibiotics in the UK $(20,22)$. Although this number fell by $45 \%$ in the mid-1990s, in the year 2000, antibiotics were still prescribed to over two-thirds of patients presenting to general practice with respiratory tract infections; $60 \%$ of whom had sore throat $(20)$.

It is now generally recognised that antibiotics have limited efficacy in the majority of patients with acute sore throats $(7,21)$, and may encourage repeated attendance for future sore throat episodes (23). The World Health Organisation guidelines have discouraged the prescribing of antibiotics for the treatment of viral sore throat (7). The National Institute for Health and Clinical Excellence (NICE) guidelines in the UK have recommended no or delayed prescribing of antibiotics for minor acute illnesses, including sore throat (8). Furthermore, reduced antibiotic prescribing may curb the development of antibioticresistance in the community (11) and reduce the overall cost burden on the healthcare system. Delaying the prescribing of antibiotics (i.e. using antibiotics only if symptoms 


\section{Available OTC sore throat remedies and the different formulations}

Compared with oral analgesic treatments, topical remedies such as throat lozenges, gargles and throat sprays (3), which are applied directly to the mucous membranes of the mouth or throat, can provide more rapid symptomatic relief in patients with acute sore throat. There are clear differences between the three topical delivery systems in the onset of action and the amount of active ingredients present in the mouth and throat. Throat sprays should ideally produce relatively coarse droplets so that they reach the desired target site. However, a proportion of the spray is immediately swallowed after application (24), thus reducing the concentration of active ingredients present in the mouth and throat. In addition, evidence suggests that owing to the gag reflex, gargles are not able to deliver the active ingredients to all areas of the throat and only deliver to the anterior oral cavity (25).

Lozenges are placed in the oral cavity where they slowly dissolve to release the active ingredients directly onto the irritated mucosal tissues. As the lozenge dissolves in the mouth, the mouth adopts a reservoir-like role for the distribution of the lozenge contents to the throat (24). Therefore, medicated throat lozenges have the added advantage of being slowreleasing. Furthermore, the portability and convenience of taking lozenges may help to facilitate good adherence/compliance to medication.

A range of active ingredients are used in topical OTC sore throat remedies (Table 1). It is not our intention to present clinical evidence for each of the sore throat treatments available 
OTC. However, we will use amylmetacresol and 2,4-dichlorobenzyl alcohol (AMC/DCBA)containing throat lozenges as a case example because of the availability of recently published data/evidence.

\section{Important features of some topical OTC sore throat remedies}

We propose that an ideal sore throat treatment, or a range of treatment products, should possess the following properties:

- Targets the causes of throat soreness, especially the viral causes and inflammation

- Provides local pain relief, eliminating the associated discomfort in the throat region

- Provides a rapid onset of action from the time that the remedy is taken or administered

- Has a prolonged duration of action, given the actual and patient-perceived prolonged nature of sore throat symptoms

- Be shown to be effective over a range of different types of sore throat (e.g. from the scratchy-like sensation causing local discomfort to the painful sore throats with a 'raw' feeling and to the inflamed, swollen throat types of sore throat)

- Should address the emotional aspects of having a sore throat by helping patients to feel better

- Should have a good safety profile

We will now consider these seven characteristics in greater detail.

\section{Targeting the causes of sore throat}

Several antiviral drugs of the neuraminidase inhibitor class have been shown to block the replication of influenza in the upper airways $(14,50)$, and thereby reduce the symptoms, including those of sore throat. However, although antiviral treatments may have a pivotal place in the treatment of URTIs (51), they are bound by several limitations. For example, they are limited by the specific nature of antiviral drugs, the fact that new strains are constantly emerging, the length of time an anti-infective takes to work and the subsequent level of reduction in inflammation that is required before clinical benefits prevail. Moreover, from the viewpoint of a patient, being able to feel well quickly is of primary importance, and so the availability of treatment (i.e. OTC, for easy access and self-management) that targets the underlying causes of sore throat to provide rapid symptomatic relief is key. Ideally, such treatments would target both the viral and inflammatory causes because evidence suggests that antiviral without anti-inflammatory effects have little symptomatic benefit for patients with a cold (52). 


\section{Pain relief}

Local symptomatic pain relief plays an important role in the management of acute sore throat (51). The influence of pro-inflammatory mediators on the pain sensation of all sore throats regardless of the cause need to be taken into consideration when making treatment choices, and should also be a target for providing symptomatic relief of symptoms, thereby reducing associated inflammation and pain.

The analgesic effect experienced with antiseptic lozenges such as AMC/DCBA throat lozenges was thought to be produced by means of its antiseptic action on bacteria and viruses (Figure 1) $(13,53,54)$. In vitro evidence demonstrated the virucidal effect of AMC and DCBA on a number of viruses associated with common cold/flu (13), and it could be anticipated that reduction of virus infectivity in saliva would reduce virus transmission to others in addition to the immediate clinical benefits of reducing soreness. However, clinical trials and human quarantine experiments would be needed to precisely quantify the antiviral effects of any lozenge in vivo.

However, recent evidence has led to the theory that such pain relief was not merely as a result of antiseptic and demulcent/moisturising action - a possible sodium channel-blocking effect was deemed to be a contributory factor and a viable mechanistic pathway (29). Sodium channels, as mediators of membrane excitability, regulate the sodium permeability of cells during the rapid rising phase of the action potential. These channels play a key role in initiation and transmission of electrical activity throughout the nervous system, with implications for sensory neuron physiology and pathophysiology, and localised inhibition of their function can prevent the perception of pain $(55,56)$. Therefore, sodium channels are thought to represent key target sites for local anaesthetic agents, such as lidocaine, to exert their analgesic effects.

Based on previous work on sodium channel-blocking properties of phenol derivatives (57-59), we hypothesised that the analgesic effect of antiseptics which carry the aromatic alcohol phenol as the core element (see Figure 2) might actually - at least partly - be due to sodium channel blocking, i.e. direct local anaesthetic-like effects.

In particular, the proposition was examined that the active ingredients AMC, DCBA and hexylresorcinol present in some antiseptic lozenges act in this manner. When the in vitro effect of AMC, DCBA and hexylresorcinol in blocking voltage-operated neuronal sodium channels heterogeneously expressed in human embryonic kidney 293 cells was investigated (29), all three agents were found to block voltage-gated sodium channels in a local 
anaesthetic-like fashion. When AMC and DCBA were investigated separately and in combination, AMC inhibited sodium inward current with a high potency; DCBA, although lower in potency than AMC, exhibited similar blocking potency to the local anaesthetic, lidocaine (29). A combination of the potent channel blocker, AMC, and the reduced potency for sodium channel blockade of DCBA attenuated the effects of AMC, possibly as a result of competitive binding. This may have in vivo benefits of limiting the overall local anaesthetic effect known as a 'ceiling' effect, so as to avoid over-numbing without compromising pain relief (29).

In addition, real-life patient experiences reported during clinical trials have demonstrated that AMC/DCBA-containing lozenges exert significantly greater reductions in mean throat discomfort levels (60), severity of throat soreness (19,60-62), offering greater pain relief $(19,60-62)$ and easing of difficulty in swallowing (19) to sore throat sufferers compared with non-medicated placebo lozenges. Furthermore, the analgesic effects of AMC/DCBA throat lozenges were clinically meaningful compared with non-medicated lozenges (19), and significant improvements in functional impairment scores were observed for swallowing, talking and eating a meal (19). Importantly, this evidence suggests that effective OTC treatments are available that not only provide effective relief of the physical symptoms, but also improve functional impairment, thus allowing patients to re-engage in their daily activities and return to their everyday lives (19).

\section{Speed of action}

When evaluating the suitability of sore throat remedies, the simple demulcent benefits should not be overlooked because demulcents, such as glycerin, honey and sugar (which form the base of throat lozenges), act to soothe the throat and reduce the irritation (2). In addition, the increased production of saliva induced by the sucking action required with lozenges that becomes evident after 1 minute (63) provides lubrication to the throat to soothe inflammation (2). Saliva production may also flush the offending microbes from the throat surface (2). Furthermore, the antiviral and antifungal constituents of saliva may protect tissues by targeting microbes, encouraging soft tissue repair, maintaining an ecological balance in the oral region and maintaining an adequate $\mathrm{pH}$ (64). Previous research has shown that AMC/DCBA-containing throat lozenges administered to healthy volunteers promote saliva production (63).

Scintigraphy studies have highlighted transit and deposition sites in the throat and have shown that the lozenge formulation can facilitate the delivery of active ingredients to the 


\section{The duration of action}

Therefore, having a long duration of action is an essential prerequisite of any remedy used. Limb et al. have demonstrated that lozenges offer a relatively prolonged activity (23). Gargles are usually gargled in the mouth for approximately 30 seconds and then are expelled whereas sprays are swallowed soon after application, but lozenges take approximately 6-9 minutes to dissolve in the mouth upon sucking (63). Scintigraphy research has shown that lozenges are an ideal vehicle for sore throat treatment owing to their reservoir-like action, offering rapid and prolonged delivery of active ingredients (24). Furthermore, studies have demonstrated that continued use of AMC/DCBA throat lozenges over a 3-day period provides significantly greater improvements in throat soreness, faster pain relief and greater easing of difficulty in swallowing compared with non-medicated lozenges (19).

\section{Effectiveness over a range of different types of sore throat}

Sore throats exhibit themselves in different ways depending on the individual and the causative factors. A combination of antiseptic, analgesic and anti-inflammatory properties of medicated lozenges, and stimulation saliva production are important attributes for a sore throat lozenge.

\section{Helping patients to feel better}

McNally et al. have recently documented the beneficial effects of a lozenge and noted that a significantly greater number of patients who took the medicated throat lozenges felt better compared with those who took the non-medicated lozenge ( $65 \%$ vs $26 \%$, respectively; 
$\mathrm{P}<0.0001)$ (19). This begins to address the emotional aspects of having a sore throat. When patients feel better, they can get back to and carry on with their everyday lives.

\section{Safety profile}

The literature available on topical OTC sore throat treatments demonstrates a good safety profile, with only very minor self-limiting adverse effects, such as headaches and coughing being reported. However, a systematic review is warranted to further evaluate this. Additionally, it is important to note that patients should take care when drinking hot beverages if using strong anaesthetics, because the local numbing effect may result in patients underestimating the exact temperatures.

\section{Conclusions}

Sore throat is considered a minor ailment but results in considerable suffering for the patient who then seeks remedial action, often at the expense of the healthcare system. A reduction in antibiotic prescribing, especially for respiratory conditions such as sore throat, is currently on the agenda of many global healthcare services to minimise bacterial resistance and unnecessary exposure of patients to potential side effects $(7-9,20)$, which in turn reduces costs. In the UK, NHS Direct has encouraged self-diagnosis and along with the mild symptoms (including sore throat) experienced by most, the extensive OTC range of medicines, such as analgesics and sore throat lozenges has played an important clinical role in communities around the world.

An 'ideal' OTC treatment for sore throat should have a minimum set of features that would render it clinically effective in providing pain relief and have additional benefits, such as those of sensorial stimulation. These 'ideal' characteristics - targeting the underlying causes, providing pain relief, having a rapid onset of action or prolonged duration and being effective over a range of different sore throat types such that the patient feels better after treatmentshould be borne in mind when making a treatment recommendation to patients, given the evidence available. 


\section{Disclosures}

Retroscreen Virology has received research contract funding from the former Boots Healthcare International, now known as Reckitt Benckiser Healthcare International, to investigate virucidal properties of lozenges. Professor J.S. Oxford has received lecture fees and travel grants from Reckitt Benckiser Healthcare International, but not related to the writing of this review article.

Professor M. Leuwer has received research contract funding from Reckitt Benckiser Healthcare International to investigate the effects of active ingredients in lozenges on voltage-operated sodium channels; no personal funding was received for the preparation of this article.

Reckitt Benckiser Healthcare International is the manufacturer of Strepsils.

\section{Acknowledgments}

The authors would like to thank Quyen Chu, PhD (a member of the European Medical Writer's Association), who was funded by Reckitt Benckiser Healthcare International for editorial support during the preparation of this manuscript. 


\section{References}

1. Writing Committee of the WHO Consultation on Clinical Aspects of Pandemic (H1N1) 2009 Influenza, Bautista E, Chotpitayasunondh T, Gao Z, et al. Clinical aspects of pandemic 2009 influenza A (H1N1) virus infection. N Engl J Med 2010; 362: 170819.

2. Marshall S: Giving advice on sore throats. Pharm J 2008; 280: 127-30.

3. Kelly F: Something for a sore throat please. Australian Pharmacist 2008; 394-97.

4. Campbell A, McGovern M, Millar $\mathrm{H}$, et al. SIGN guidelines and the management of sore throat in community pharmacy. Int J Pharm Pract 2001; 9: R15.

5. Parmet S, Lynm C, Glass RM. JAMA patient page. Sore throat. JAMA 2004; 291: 1664.

6. Royal College of General Practitioners Birmingham Research Unit: Weekly Returns Service Annual Prevalence Report 2007.

[http://www.rcgp.org.uk/pdf/BRU\%20Annual\%20prevalence\%20report\%202007.pdf]

7. Avorn JL, Barrett JF, Davey PG, McEwen SA, O'Brien TF, Levy SB. Antibiotic resistance: synthesis of recommendations by expert policy groups. World Health Organisation 2001 [http://whqlibdoc.who.int/hq/2001/WHO_CDS_CSR_DRS_2001.10.pdf]

8. NICE. NICE guidelines: Respiratory tract infections - antibiotic prescribing: prescribing antibiotics for self-limiting respiratory tract infections in adults and children in primary care. NICE clinical guideline 69. NICE: London; 2008 [http://www.nice.org.uk/nicemedia/pdf/CG69FullGuideline.pdf]

9. SIGN. SIGN guidelines. Management of sore throat and indications for tonsillectomy. 1999. [http://www.show.scot.nhs.uk/sign/home.htm]

10. National Guideline Clearinghouse (NGC). Guideline synthesis: Pharyngitis/sore throat. In: National Guideline Clearinghouse (NGC) website. Rockville (MD): 1999 Oct 6 (revised 2005 Dec). [http://www.guideline.gov]

11. Summers A. Sore throats. Accid Emerg Nurs 2005; 13: 15-17.

12. Worrall GJ. Acute sore throat. Can Fam Physician 2007, 53: 1961-62. 
13. Oxford JS, Lambkin R, Gibb I, et al. A throat lozenge containing amylmetacresol and dichlorobenzyl alcohol has a direct virucidal effect on respiratory syncytial virus, influenza A and SARS-CoV. Antivir Chem Chemother 2005, 16: 129-34.

14. Collier L, Oxford J. Human Virology. New York: Oxford University Press; 2006.

15. Centor RM. Expand the pharyngitis paradigm for adolescents and young adults. Ann Intern Med 2009, 151: 812-15.

16. Eccles R. Mechanisms of symptoms of the common cold and influenza. Br J Hosp Med (Lond) 2007; 68: 71-75.

17. Capuron L, Miller AH. Cytokines and psychopathology: lessons from interferon-alpha. Biol Psychiatry 2004; 56: 819-24.

18. Lindbaek M, Francis N, Cannings-John R, et al. Clinical course of suspected viral sore throat in young adults: cohort study. Scand J Prim Health Care 2006; 24: 93-7.

19. McNally D, Saddiq M, Simpson M, et al. Rapid relief of acute sore throat with AMC/DCBA throat lozenges: randomised controlled trial. Int J Clin Pract 2010; 64: 194-207 [Epub 2009 Oct 22].

20. Ashworth M, Latinovic R, Charlton J, et al. Why has antibiotic prescribing for respiratory illness declined in primary care? A longitudinal study using the General Practice Research Database. J Public Health (Oxf) 2004; 26: 268-74.

21. Del Mar CB, Glasziou PP, Spinks AB. Antibiotics for sore throat. Cochrane Database Syst Rev 2006: CD000023.

22. Sharland $M$, Kendall $H$, Yeates $D$, et al. Antibiotic prescribing in general practice and hospital admissions for peritonsillar abscess, mastoiditis, and rheumatic fever in children: time trend analysis. BMJ 2005; 331: 3289.

23. Little $P$, Gould C, Williamson I, et al. Reattendance and complications in a randomised trial of prescribing strategies for sore throat: the medicalising effect of prescribing antibiotics. BMJ 1997; 315: 350-52.

24. Limb M, Connor A, Pickford M, et al. Scintigraphy can be used to compare efficacy of sore throat formulations. Int J Clin Pract. 2009; 63: 606-12.

25. Becker WN, Naumann HH, Pfaltz CR. Ear, nose and throat diseases: A pocket reference (Authorised translation) 3rd Ed. Stuttgart: Georg Thieme Verlag; 1989. 
26. Weiser T, Wilson N. Inhibition of tetrodotoxin (TTX)-resistant and TTX-sensitive neuronal $\mathrm{Na}(+)$ channels by the secretolytic ambroxol. Mol Pharmacol 2002; 62: 433-38.

27. Schutz A, Gund HJ, Pschorn U, et al. Local anaesthetic properties of ambroxol hydrochloride lozenges in view of sore throat. Clinical proof of concept. Arzneimittelforschung 2002; 52: 194-99.

28. Fischer J, Pschorn U, Vix JM, et al. Efficacy and tolerability of ambroxol hydrochloride lozenges in sore throat. Randomised, double-blind, placebo-controlled trials regarding the local anaesthetic properties. Arzneimittelforschung 2002; 52: 256-63.

29. Buchholz V, Leuwer M, Ahrens J, et al. Topical antiseptics for the treatment of sore throat block voltage-gated neuronal sodium channels in a local anaesthetic-like manner. Naunyn Schmiedebergs Archiv Pharmacol 2009; 380: 161-68 [Epub 2009 Apr 15].

30. Dempster JH. Post-tonsillectomy analgesia: the use of benzocaine lozenges. $J$ Laryngol Otol 1988; 102: 813-14.

31. Kagan G, Huddlestone L, Wolstencroft P. Two lozenges containing benzocaine assessed in the relief of sore throat. $J$ Int Med Res 1982; 10: 443-46.

32. Froom J, Boisseau V. Benzydamine oral rinse for sore throat. Curr Ther Res 1979; 26: 856-61.

33. Wethington JF. Double-blind study of benzydamine hydrochloride, a new treatment for sore throat. Clin Ther 1985; 7: 641-46.

34. Young JR. A comparative study of benzydamine hydrochloride ("Difflam" pump spray) and placebo as analgesics following tonsillectomy. Int J Tissue React 1987; 9: 131-33.

35. Chudoba VA. Benzydamine hydrochloride: oral rinse for chronic pharyngitis in tonsillectomized patients. Mod Med Canada 1983; 38: 1388-92.

36. Whiteside MW. A controlled study of benzydamine oral rinse ("Difflam") in general practice. Curr Med Res Opin 1982; 8: 188-90. 
37. Agarwal A, Nath SS, Goswami D, et al. An evaluation of the efficacy of aspirin and benzydamine hydrochloride gargle for attenuating postoperative sore throat: a prospective, randomized, single-blind study. Anesth Analg 2006; 103: 1001-03.

38. Richards RM, Xing JZ, Mackay KM. Excipient interaction with cetylpyridinium chloride activity in tablet based lozenges. Pharm Res 1996; 13: 1258-64.

39. Zejdl J, Butt U, Gorlich HD. [Positive review of sugar-free CPC lozenges]. Therapiewoche 1990; 40: 3769-73.

40. Benrimoj SI, Langford JH, Christian J, et al. Efficacy and tolerability of the antiinflammatory throat lozenge flurbiprofen $8.75 \mathrm{mg}$ in the treatment of sore throat: a randomised, double-blind, placebo-controlled study. Clin Drug Investig 2001; 21 : 183-93.

41. Watson N, Nimmo WS, Christian J, et al. Relief of sore throat with the antiinflammatory throat lozenge flurbiprofen $8.75 \mathrm{mg}$ : a randomised, double-blind, placebo-controlled study of efficacy and safety. Int J Clin Pract 2000; 54: 490-96.

42. Blagden $\mathrm{M}$, Christian J, Miller $\mathrm{K}$, et al. Multidose flurbiprofen $8.75 \mathrm{mg}$ lozenges in the treatment of sore throat: a randomised, double-blind, placebo-controlled study in UK general practice centres. Int J Clin Pract 2002; 56: 95-100.

43. Bokor M. The effect of hexetidine spray on dental plaque following periodontal surgery. J Clin Periodontol 1996; 23: 1080-83.

44. Klingbeil W. [Therapy of acute diseases of the upper airway. Comparison of 2 antiseptic pharyngeal sprays in otorhinolaryngologic practice]. Fortschr Med 1982; 100: 146-49.

45. Sweetman SC (ed). Martindale: The Complete Drug Reference $\left(35^{\text {th }} \mathrm{Ed}\right)$. London: The Pharmaceutical Press; 2007.

46. Leuwer M, Haeseler G, Hecker $\mathrm{H}$, et al. An improved model for the binding of lidocaine and structurally related local anaesthetics to fast-inactivated voltageoperated sodium channels, showing evidence of cooperativity. Br J Pharmacol 2004; 141: 47-54.

47. Bienen H, Raus I. [Therapeutic comparison of throat lozenges (author's transl)]. MMW Munch Med Wochenschr 1981; 123: 745-47. 
48. Al-Bayati FA. Isolation and identification of antimicrobial compound from Mentha longifolia L. Leaves grown wild in Iraq. Ann Clin Microbiol Antimicrob 2009; 12: 20.

49. Haeseler G, Maue D, Grosskreutz J, et al. Voltage-dependent block of neuronal and skeletal muscle sodium channels by thymol and menthol. Eur J Anaesthesiol 2002; 19: $571-79$.

50. Gubareva LV, Kaiser L, Hayden FG. Influenza virus neuraminidase inhibitors. Lancet 2000; 355: 827-35.

51. Roxas M, Jurenka J. Colds and influenza: a review of diagnosis and conventional, botanical, and nutritional considerations. Altern Med Rev 2007; 12: 25-48.

52. Johnston SL. Problems and prospects of developing effective therapy for common cold viruses. Trends Microbiol 1997; 5: 58-63.

53. Richards ME. Inhibitory activity of lozenges on oral bacteria. [Abstract No.168] Pharmacotherapy 1988; 8: 142.

54. Richards RM, Xing DK. In vitro evaluation of the antimicrobial activities of selected lozenges. J Pharm Sci 1993; 82: 1218-20.

55. Priestley T. Voltage-gated sodium channels and pain. Curr Drug Targets CNS Neurol Disord 2004; 3: 441-56.

56. Wood JN, Boorman JP, Okuse K, et al. Voltage-gated sodium channels and pain pathways. J Neurobiol 2004; 61: 55-71.

57. Haeseler G, Bufler J, Merken S, et al. Block of voltage-operated sodium channels by 2,6-dimethylphenol, a structural analogue of lidocaine's aromatic tail. Br J Pharmacol 2002; 137: 285-93.

58. Haeseler G, Karst M, Foadi N, et al. High-affinity blockade of voltage-operated skeletal muscle and neuronal sodium channels by halogenated propofol analogues. Br J Pharmacol 2008; 155: 265-75.

59. Haeseler G, Piepenbrink A, Bufler J, et al. Structural requirements for voltagedependent block of muscle sodium channels by phenol derivatives. Br J Pharmacol 2001; 132: 1916-24.

60. Berry P. Rapid relief of acute sore throat with Strepsils lozenges: a single-blind, comparative study. In: Oxford JS, ed. Developments in acute sore throat relief - 
61. Marazzi PJ. Strepsils anaesthetic lozenges versus control Strepsils lozenges in the relief of moderate-to-severe sore throat: a double-blind, cross-over, multiple-dose, randomized study. In: Oxford JS, ed. Developments in acute sore throat relief efficacy and sensorial benefits of medicated lozenges. London: Royal Society of Medicine Press Ltd. 2008; 13-21.

62. Wade AG. A randomized, double-blind, parallel-group, placebo-controlled, multipledose study of the efficacy of Strepsils lozenges in the relief of acute sore throat. In: Oxford JS, ed. Developments in acute sore throat relief - efficacy and sensorial benefits of medicated lozenges. London: Royal Society of Medicine Press Ltd. 2008; 22-32.

63. Wade AG, Marshall LE, Simpson, M et al. Bioavailability and efficacy of active lozenges in the relief of sore throat pain. Poster presented at the Annual Scientific Meetings of The British Pain Society, 24-27 April 2007. Glasgow, UK.

64. Mandel ID. The functions of saliva. J Dent Res 1987; 66 (Spec No): 623-27. 
Figure 1: The mechanism of action of AMC/DCBA-induced destruction of viruses (13)
A. Control virions incubated for 4 minutes in artificial saliva buffer solution. Virions are evenly distributed. (Magnification approximately 9k)

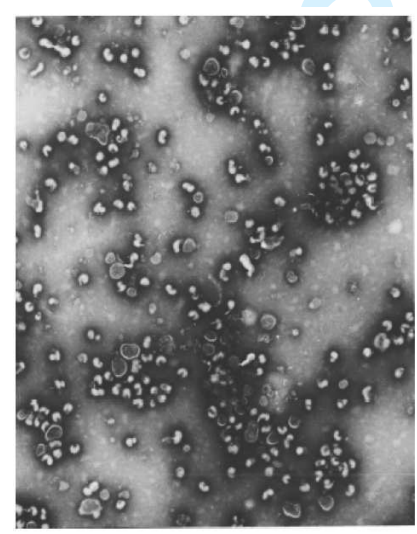

B. Control virions incubated for 4 minutes with the virucidal lozenge mixture. Note clumped virions.

(Magnification approximately 9k)

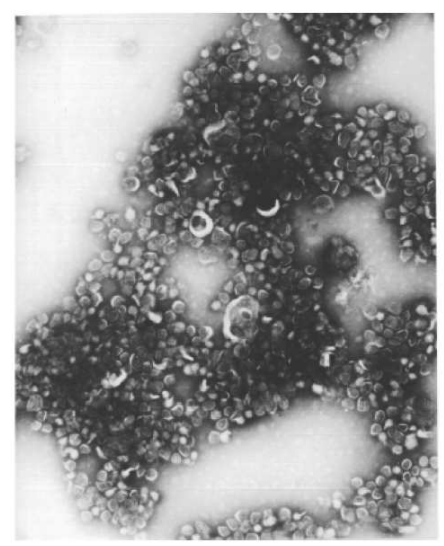


Figure 2: Structures of AMC, DCBA and hexylresorcinol<smiles>OCc1ccc(Cl)cc1Cl</smiles><smiles>CCCCCc1ccc(C)cc1O</smiles>

2,4-dichloro-benzylalcohol

Amylmetacresol

Hexylresorcinol 
Table 1: Main active ingredients present in some typical OTC sore throat treatments and their mode of action

\begin{tabular}{|c|c|c|c|c|}
\hline Active ingredient & $\begin{array}{l}\text { Formulation } \\
\text { type(s) }\end{array}$ & $\begin{array}{l}\text { Products } \\
\text { containing } \\
\text { these } \\
\text { ingredients }\end{array}$ & Mechanism of action & References \\
\hline $\begin{array}{l}\text { Ambroxol } \\
\text { hydrochloride }\end{array}$ & Lozenges & Mucoangin ${ }^{\mathrm{TM}}$ & $\begin{array}{l}\text { Local anaesthetic; acts on } \\
\text { the neuronal voltage-gated } \\
\text { Na channels in sensory } \\
\text { neurones (29) }\end{array}$ & $\begin{array}{l}\text { Weiser and Wilson, } 2002 \\
\text { (26); Schutz et al, } 2002 \\
\text { (27); Fischer et al, } 2002 \\
\text { (28) }\end{array}$ \\
\hline Amylmetacresol & $\begin{array}{l}\text { Spray, } \\
\text { lozenges }\end{array}$ & Strepsils ${ }^{\circledR}$ & $\begin{array}{l}\text { Antibacterial; antiviral; local } \\
\text { anaesthetic; blocks voltage- } \\
\text { gated Na channels in a } \\
\text { local anaesthetic-like } \\
\text { manner }\end{array}$ & Buchholz et al, 2009 (29) \\
\hline $\begin{array}{l}\text { Benzocaine } \\
\text { (ethylaminobenzoate) }\end{array}$ & $\begin{array}{l}\text { Cream, gel, } \\
\text { spray, } \\
\text { lozenges }\end{array}$ & $\begin{array}{l}\text { Merocaine }^{(} ; \\
\text {Tyrozet }^{\circledR} \text {, } \\
\text { Chloraseptic, } \\
\text { Dequacaine }^{\circledR}\end{array}$ & $\begin{array}{l}\text { Local anaesthetic (ester- } \\
\text { type) }\end{array}$ & $\begin{array}{l}\text { Dempster, } 1988 \text { (30); } \\
\text { Kagan et al, } 1982 \text { (31) }\end{array}$ \\
\hline Benzydamine $\mathrm{HCl}$ & $\begin{array}{l}\text { Throat } \\
\text { spray, } \\
\text { gargles, } \\
\text { lozenges }\end{array}$ & $\begin{array}{l}\text { Tantum Verde, } \\
\text { Difflam }\end{array}$ & $\begin{array}{l}\text { Non-steroidal anti- } \\
\text { inflammatory drug (NSAID); } \\
\text { some local anaesthetic } \\
\text { activity }\end{array}$ & $\begin{array}{l}\text { Froom and Boisseau, } \\
1979 \text { (32); Wethington, } \\
1985(33) ; \text { Young, } 1987 \\
\text { (34); Chudoba, } 1983(35) ; \\
\text { Whiteside, } 1982(36) ; \\
\text { Agarwal et al, } 2006 \text { (37) }\end{array}$ \\
\hline $\begin{array}{l}\text { Cetylpyridinium } \\
\text { chloride }\end{array}$ & $\begin{array}{l}\text { Lozenges, } \\
\text { throat sprays }\end{array}$ & $\begin{array}{l}\text { Merocets }^{(}, \\
\text {Merocaine }\end{array}$ & Antibacterial & $\begin{array}{l}\text { Richards et al, } 1996 \text { (38); } \\
\text { Zejdl et al, } 1990 \text { (39) }\end{array}$ \\
\hline $\begin{array}{l}\text { 2,4-dichlorobenzyl } \\
\text { alcohol }\end{array}$ & $\begin{array}{l}\text { Spray, } \\
\text { lozenges }\end{array}$ & Strepsils ${ }^{\circledR}$ & $\begin{array}{l}\text { Antibacterial; antiviral; local } \\
\text { anaesthetic; blocks voltage- } \\
\text { gated Na channels in a } \\
\text { local anaesthetic-like } \\
\text { manner }\end{array}$ & Buchholz et al, 2009 (29) \\
\hline Flurbiprofen & $\begin{array}{l}\text { Sprays, } \\
\text { gargle, } \\
\text { lozenges }\end{array}$ & Strefen $^{\circledR}$ & Anti-inflammatory; NSAID & $\begin{array}{l}\text { Benrimoj et al, } 2001(40) ; \\
\text { Watson et al, } 2000(41) ; \\
\text { Blagden, } 2002(42)\end{array}$ \\
\hline Hexetidine & $\begin{array}{l}\text { Throat } \\
\text { spray, mouth } \\
\text { spray, } \\
\text { lozenges }\end{array}$ & Hexoral & Antiseptic effects & $\begin{array}{l}\text { Bokor, } 1996 \text { (43); } \\
\text { Klingbeil, } 1982(44)\end{array}$ \\
\hline Hexylresorcinol & Lozenges & Strepsils Extra ${ }^{\circledR}$ & $\begin{array}{l}\text { Antiseptic; local } \\
\text { anaesthetic; blocks voltage- } \\
\text { gated Na channels in a } \\
\text { local anaesthetic-like } \\
\text { manner }\end{array}$ & $\begin{array}{l}\text { Martindale } 35^{\text {th }} \text { Ed, } 2007 \\
\text { (45); Buchholz et al, } 2009 \\
\text { (29) }\end{array}$ \\
\hline Lidocaine $\mathrm{HCl}$ & $\begin{array}{l}\text { Spray, gel, } \\
\text { lozenges }\end{array}$ & $\begin{array}{l}\text { Strepsils Plus }{ }^{\circledR}, \\
\text { Dequaspray }\end{array}$ & $\begin{array}{l}\text { Local anaesthetic (amide- } \\
\text { type): blocks voltage-gated } \\
\text { Na channels }\end{array}$ & $\begin{array}{l}\text { Martindale 35th Ed, } 2007 \\
\text { (45); Leuwer et al, } 2004 \\
\text { (46); Buchholz et al, } 2009 \\
\text { (29) }\end{array}$ \\
\hline $\begin{array}{l}\text { Muramidase } \mathrm{HCl} \\
\text { (lysozyme) }\end{array}$ & $\begin{array}{l}\text { Lozenges, } \\
\text { mouth rinses }\end{array}$ & Lysopaine & $\begin{array}{l}\text { Antibacterial; hydrolysis of } \\
\text { glycosidic linkage of } \\
\text { peptoglycan in bacterial cell } \\
\text { walls }\end{array}$ & $\begin{array}{l}\text { Bienen and Raus, } 1981 \\
\text { (47) }\end{array}$ \\
\hline $\begin{array}{l}\text { Volatile oils (i.e. } \\
\text { menthol) }\end{array}$ & Lozenges & Halls, Lockets & $\begin{array}{l}\text { Antibacterial, local } \\
\text { anaesthetic; blocks voltage- } \\
\text { gated Na channels }\end{array}$ & $\begin{array}{l}\text { Al-Bayati, } 2009 \text { (48); } \\
\text { Martindale } 35^{\text {th }} \text { Ed, } 2007 \\
\text { (45); Haeseler et al, } 2002 \\
\text { (49) }\end{array}$ \\
\hline
\end{tabular}

${ }^{\star}$ Not all products are licensed for OTC sale in every country 